\title{
TEACHING ENGLISH BASED ON 2013 CURRICULUM AT JUNIOR HIGH SCHOOL IN GOWA
}

\author{
Zohra Inayah Nasir \\ English Education Department of UIN Alauddin Makassar \\ robrainayahnasin@gmail.com
}

\begin{abstract}
The objective of this study was to describe the ability of teachers in four piloting schools in applying the 2013 curriculum. It was conducted at four piloting junior high schools in Gowa. This research consisted of four samples, and researcher used the purposive sampling. The data were collected by using observation sheet in observing the teacher's mastery toward the learning concept based on 2013 curriculum, teachers' ability in constructing the lesson plan as recommended by 2013 curriculum, the teachers' ability in applying the scientific approach at class, and teachers' ability in assesing based on 2013 curriculum rules. In analyzing the data, researcher used descriptive quantitative. After analyzing the data, it was found that the teachers' understanding about 2013 curriculum in teaching English are very good with the SMPN 1 Bontomaranu's score is 90, SMPN 3 Sungguminsa's score is 91, SMPN 1 Sungguminasa's score is 92, SMPN 1 Pallangga's score is 94. Therefore, the researcher suggested to the teacher who have been observed to sustain their ability about 2013 curriculum and also spread their ability to the other teacher who did not really understand yet about the 2013 curriculum for better English teaching and education in Gowa.
\end{abstract}

KEY WORDS: Teaching English, 2013 Curriculum.

\section{A. INTRODUCTION}

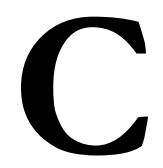

urriculum is an important tool for the success of education. Without appropriate curriculum, it is difficult to reach the goal of education. In the history of education of Indonesia, Indonesia has several times in held curriculum change and improvement to adapting the curriculum with improvement and progress of time in order to achieve the maximum result. Curriculum change based on awareness that development and change that occur in society in Indonesia, global challenge, development of science and technology. This continuous change requires the improvement of national education system, include the completion of curriculum in realizing a society who are able to compete and adapt with the change.

Muhammad Nuh as Ministry of Education at the time, asserted that 2013 curriculum designed as an attempt to prepare the future generation in 2045, when 
100 years independent of Indonesia and also utilizing the numerous productive age in 2045 to be a demographic bonus. (Mida Latifatul Huzamiroh, 2013: 111-112). In its implementation, the curriculum change gets the pros and cons in society. One of the problems that occur was the teacher preparation to face it. Nevertheless, government continues to implement the change of 2013 curriculum by reason quality education improvement. The Decree of The Ministry of Education (Permendiknas) chapter 71 in 2013 about the curriculum structure explains that 2013 curriculum aims at preparing the Indonesia generation in order they are able to live as a faithful, productive, innovative, creative, affective, and contributive in life society, nation, state, and also civilization. Besides, one of the efforts to support the 2013 curriculum is preparing the teacher to face it. The way to make it real is implementation of training toward the teacher in Indonesia about the 2013 curriculum. This training aims to produce the competent teacher in applying the scientific approach in 2013 curriculum when they are teaching.

The 2013 curriculum also has a similar basic with the basic competency of curriculum (curriculum before KTSP) which aims to create the competent and competitive students. Indonesia Government also said that 2013 curriculum is not something new, it is a development from the previous curriculum (KTSP). According to them, in 2013 curriculum there is addition in teaching material that do not exist in previous curriculum, also the elimination of unimportant, and sustain the relevant one. Furthermore, the education in Indonesia is necessary to formulate a curriculum that emphasize in personal experience through the process of observing, questioning, reasoning, and trying to increase the learner's creativity and prior the attitude, knowledge, and skill aspect. By the consideration, Government through Ministry of Education and Culture start the changes in several schools in academic years 2013/2014 at several piloting schools and implement it nationally in 2014 (Purnomo, 2013).

In the implementation of 2013 curriculum for one semester nationally, researcher perceives the importance of doing a research about the implementation of the curriculum. The research will be an evaluation for better and also give the readers important information about the sustainability of 2013 curriculum in Gowa. In this research, Gowa, one of regency in South Sulawesi, is elected regency by the research because Gowa is the regency that sustain implementation of 2013 curriculum after the decree of ministry of education (Permendiknas) chapter 160 in 2014 decide that there are two curriculums that use in Indonesia. KTSP and 2013 curriculum. School 
that implemented curriculum since academic years 2013/2014, continued the implementation of 2013 curriculum, and several schools that implemented 2013 curriculum since academic years 2014/2015 back to 2006 curriculum (KTSP).

In this study, researcher also focuses on English subject. In 2013 curriculum, English is one of controversial subject that discussed by the people because several issues which related to English subject, particularly in junior high school. Those issues are about the elimination of English, reduction of learning time in English subject, and the range of English material in English syllabus. In fact, these issues are totally contradictive with the demands of time, remembering that now Indonesia prepares the generation to face the ASEAN Economy Community, and English is very important here.

Therefore, the researcher intends to find out the fact about the learning English base on 2013 curriculum at Junior high school in Gowa. This research will present information about the sustainability of 2013 curriculum in Gowa, as regency that sustain the implementation of 2013 curriculum after the decree of Ministry of Education chapter 160 in 2014 and also be an evaluation about teacher ability after the 2013 curriculum training that was held during three weeks in Gowa on May 2014.

\section{B. LITERATURE REVIEW}

Abdur Rofik (2014) in his thesis said that in Wonosobo, Central Java the implementation of 2013 curriculum is still not maximal. The constraints which faced is the mindset change from previous curriculum (KTSP) to the new curriculum (2013 curriculum), facilities and infrastructure, financial, preparation of learning tools, and the complexity of the assessment particularly in attitude assessment.

Sukirno (2014) in his thesis said that the implementation of Curriculum 2013 in the English language teaching and learning at SMP 1 Kajen Pekalongan does not completely run well and in an appropriate order. The teachers have not fully implemented the scientific approach and authentic assessment. This is due to the teachers' understanding on the curriculum which still lacking and their limited teaching time. In the English language teaching and learning, the English language teachers of SMP 1 Kajen Pekalongan have some difficulties in the implementation of Curriculum 2013. These difficulties include lesson time which is relatively not enough to implement the scientific approach and authentic assessment, some students who still have low learning motivation, and the differences in teachers' understanding of Curriculum 2013, and the English language teachers made some 
efforts to overcome the difficulties in question. These efforts include the use of interactive teaching and participating in various trainings and workshops related to Curriculum 2013 in the school or district MGMP.

Tutus Lianawati (2014) said in her thesis that the problems which are faced by the teachers not only caused by the teachers but also caused by the students and the government. There are 14 kinds of problems that are faced by the English teachers in implementing curriculum 2013 of SMAN 1 Kudus in academic year 2013/2014. According to the English teachers, from 14 kinds of problems there are 11 problems coming from the teachers themselves. Then, 2 problems come from students, and 1 problem comes from the government.

Based on the previous finding above, researcher concludes that the implementation of 2013 curriculum in English subject in several schools in Java does not completely run well and appropriate. So that the researcher interested in studying about the teaching English based on 2013 curriculum at junior high school in South Sulawesi, especially in Gowa.

\section{RESEARCH METHOD}

This research is descriptive quantitative research, where the researcher describes about the facts that occur in field objectively without generalizing.

\section{The variables of this research are:}

1. The English teacher's comprehension about the learning concept based on 2013 curriculum.

2. The English teacher ability in constructing the lesson plan based on the rules in 2013 curriculum.

3. The learning process based on scientific approach in class.

4. The English teacher's ability in assessing based on the rules in 2013 curriculum.

In conducting research, the researcher needs to choose number of population as the object of research. It was necessary to be done as the first step in determining a sample from population. Sugiyono said in his book that population is the generalized of the object/ subject that had certain qualities and characteristic determined by the researcher to learn and then draw the conclusion. (Sugiyono, 2013:117). The population in this researcher is all Junior High Schools (105 Junior High School) in highland and lowland area in Gowa regency. The samples of this research are several piloting schools in Gowa. It uses purposive sampling. 


\section{The instruments which used by the researcher in this research are:}

\section{Observation Sheet}

In this research, the researcher uses four observation sheets. The first observation sheet is used to measure the English teacher's comprehension about the learning concept as recommended by 2013 curriculum. The second observations sheet is to measure the teacher's ability in constructing the lesson plan based on the rules in 2013 curriculum. The third observation sheet is the learning process observation. And the fourth observation sheet is English teacher's ability in assessing based on the rules in 2013 curriculum.

\section{Interview}

Besides observation sheets, researcher also do the interview to get more information. To measure the English teacher comprehension, the interview process takes more roles in helping the researcher especially in observing the teachers' mastery about learning concept based on 2013 curriculum when they are teaching.

In collecting data, researcher takes several steps:

a. Determine the schools that will be the subject of research. Research find out the information about the junior high school in Gowa regency that really present of all of junior high school in Gowa.

b. Preliminary study, interviewing the teachers and also the principal.

c. Come to the research subject to get the data by observe the English teacher's comprehension about learning concept as recommended by 2013 curriculum.

1) Observe the teacher's comprehension about learning concept based on 2013 curriculum.

2) Observe document (the lesson plan)

3) Observe the English learning process in class

4) Observe the assessment process

This research is the descriptive quantitative research and the researcher describes all the variables that have observed. The researcher collects the data by observing and also interviewing the teachers. In observation sheet, there are numeric data and several scales to categorize the numeric data from the observation sheet. After researcher categorize its, researchers describe the result of the observation for each variable and describes it clearly. 


\section{FINDING AND DISCUSSION}

The findings of the research were based on the results of the data analysis. The data analysis consisted of several component for each school.

Table 1, The Result of Observation in Four Piloting Junior High Schools in Gowa.

\begin{tabular}{|c|c|c|c|}
\hline School & Component & Score & Category \\
\hline \multirow[t]{4}{*}{$\begin{array}{c}\text { SMPN } 1 \\
\text { Bontomarannu }\end{array}$} & $\begin{array}{l}\text { English teachers comprehension about } \\
\text { the learning concept based on } 2013 \\
\text { curriculum }\end{array}$ & 96 & Very Good \\
\hline & $\begin{array}{l}\text { The English teacher ability in } \\
\text { constructing the lesson plan based on } \\
2013 \text { curriculum }\end{array}$ & 89 & Good \\
\hline & $\begin{array}{l}\text { The learning process based on } \\
\text { scientific approach in class }\end{array}$ & 92 & Very Good \\
\hline & $\begin{array}{l}\text { The English teachers' ability in } \\
\text { assessing based on the rules in } 2013 \\
\text { curriculum }\end{array}$ & 84 & Good \\
\hline \multirow[t]{4}{*}{$\begin{array}{c}\text { SMPN } 3 \\
\text { Sungguminasa }\end{array}$} & $\begin{array}{l}\text { English teachers comprehension about } \\
\text { the learning concept based on } 2013 \\
\text { curriculum }\end{array}$ & 96 & Very Good \\
\hline & $\begin{array}{l}\text { The English teacher ability in } \\
\text { constructing the lesson plan based on } \\
2013 \text { curriculum }\end{array}$ & 90 & Very Good \\
\hline & $\begin{array}{l}\text { The learning process based on } \\
\text { scientific approach in class }\end{array}$ & 94 & Very Good \\
\hline & $\begin{array}{l}\text { The English teachers' ability in } \\
\text { assessing based on the rules in } 2013 \\
\text { curriculum }\end{array}$ & 84 & Good \\
\hline \multirow[t]{3}{*}{$\begin{array}{c}\text { SMPN } 1 \\
\text { Sungguminasa }\end{array}$} & $\begin{array}{l}\text { English teachers comprehension about } \\
\text { the learning concept based on } 2013 \\
\text { curriculum }\end{array}$ & 96 & Very Good \\
\hline & $\begin{array}{l}\text { The English teacher ability in } \\
\text { constructing the lesson plan based on } \\
2013 \text { curriculum }\end{array}$ & 92 & Very Good \\
\hline & The learning process based on & 97 & Very Good \\
\hline
\end{tabular}


Zohra Inayah Nasir, Teaching English Based on 2013 Curriculum at Junior High School in Gowa

\begin{tabular}{|c|l|c|c|}
\hline & scientific approach in class & & \\
\cline { 2 - 5 } & $\begin{array}{l}\text { The English teachers' ability in } \\
\text { assessing based on the rules in 2013 } \\
\text { curriculum }\end{array}$ & 82 & Good \\
\hline PMPN 1 & $\begin{array}{l}\text { English teachers comprehension about } \\
\text { the learning concept based on 2013 } \\
\text { curriculum }\end{array}$ & 95 & Very Good \\
\cline { 2 - 5 } & $\begin{array}{l}\text { The English teacher ability in } \\
\text { constructing the lesson plan based on } \\
\text { 2013 curriculum }\end{array}$ & 95 & Very Good \\
\cline { 2 - 5 } & $\begin{array}{l}\text { The learning process based on } \\
\text { scientific approach in class }\end{array}$ & 95 & Very Good \\
\cline { 2 - 4 } & $\begin{array}{l}\text { The English teacher's ability in } \\
\text { assessing based on the rules in 2013 } \\
\text { curriculum }\end{array}$ & 82 & Good \\
\hline
\end{tabular}

Table 2, The Total Score of Four Piloting Junior High Schools in Gowa.

\begin{tabular}{|l|c|c|}
\hline \multicolumn{1}{|c|}{ School } & Total Score (Average) & Category \\
\hline SMPN 1 Bontomarannu & 90 & Very Good \\
\hline SMPN3 Sungguminasa & 91 & Very Good \\
\hline SMPN 1 Sungguminasa & 91 & Very Good \\
\hline SMPN 1 Pallangga & 91 & Very Good \\
\hline
\end{tabular}

Based on approach in curriculum development in previous chapter, the curriculum change to 2013 curriculum using the top down approach, because it initiated by education official with the command system. But it is not applies in all of school directly. In the first step, the school which applies the 2013 curriculum is particular school with specific criteria. By the time, the government tries to apply it nationally. In fact, there are some obstacles that faced during the implementation of 2013 curriculum and its make the government decides to apply the 2013 curriculum in several schools that called piloting school. In Gowa regency, from 105 junior high schools, there are six junior high schools, and researcher decides to observe four schools. 
According to result of observation about teaching English based on 2013 curriculum at junior high school in Gowa at the previous explanation, the ability of teachers in mastering several things in 2013 curriculum are good. It showed us that almost all of teacher in four piloting school got $>80$ in, mastering the learning concept based on 2013 curriculum, construct the lesson plan, and implement the learning activity based on 2013 curriculum also assess based on the rule in 2013 curriculum.

Table 3, The Average of Achievement of Four Piloting Schools in Gowa.

\begin{tabular}{|c|l|c|c|}
\hline NO & \multicolumn{1}{|c|}{ Components } & Average & Category \\
\hline 1 & $\begin{array}{l}\text { English teachers comprehension about the } \\
\text { learning concept based on 2013 curriculum }\end{array}$ & 97 & Very Good \\
\hline 2 & $\begin{array}{l}\text { The English teacher ability in constructing } \\
\text { the lesson plan based on 2013 curriculum }\end{array}$ & 91 & Very Good \\
\hline 3 & $\begin{array}{l}\text { The learning process based on scientific } \\
\text { approach in class }\end{array}$ & 95 & Very Good \\
\hline 4 & $\begin{array}{l}\text { The English teachers' ability in assessing } \\
\text { based on the rules in 2013 curriculum }\end{array}$ & 83 & Good \\
\hline
\end{tabular}

The table above is about the average of four things that have observed by the researcher. The highest average is in teacher understanding toward the process and assessment in learning based on 2013 curriculum with the average 97. Next, about the teacher ability in applying the 2013 curriculum in learning process with the average 95, and the teacher ability in arranging lesson plan based on 2013 curriculum's average is 91 . The last is the teacher understanding in assessing based on 2013 curriculum with the average 83 .

For more information about the four things that observed, researcher also asks the teachers about their school condition. Researcher gets some information which supports the result of research. In four piloting schools which have observed, three of four schools are in very good predicate accreditation (A), and one school in good predicate accreditation (B). As the part in education field, we know that accreditation is the systematic comprehensive assessment. It consists of internal assessment (by school it's self) and external assessment (visitation) to determine the quality of school (Ara Hidayat, 2010:182). Accreditation process is the open comprehension assessment about several things: content standard, process standard, 
graduate competency standard, teacher and educational personnel standard, standard of facilities and infrastructure, management standard, financing standard, and educational assessment standard. The several standards that observed and the result of accreditation in four piloting school gives the researcher start sight that the schools which observed are generally good.

Then, researcher tries to ask about the 2013 curriculum training. 2013 curriculum training that held by the government in Gowa regency on May 2014 during three weeks, gives the positive effect for the teacher to implement the 2013 curriculum. The 2013 curriculum training generally has three objectives: for teachers, they are guided to be open mind toward the curriculum changes. Then, after following the 2013 curriculum training, teachers are expected to able in handling their job accordance with the demand of graduate competency, content, learning process, and assessment in 2013 curriculum. For principals, they are expected to mobilize the resources to ensure the success of 2013 curriculum implementation. And for the supervisor, they are expected to give the technical assistance and help the school to overcome the obstacle that faced during the implementation of 2013 curriculum at school.

Researcher observes that the cooperation between the teachers who have observed and the principal in each school is very good. Specifically for teacher, researcher gets more information that 2013 curriculum training helps them in understanding the 2013 curriculum deeply (philosophically, implementation strategy, core competency, and basic competency), so they have a strong desire to implement 2013 curriculum at their school. They are also guided in arranging the lesson plan based on 2013 curriculum, skill in apply the problem based learning, project based learning and discovery learning and authentic assessment, also have a good skill in communication in trace and politely.

Besides 2013 curriculum training, researcher gets information which supports the result of observation result. It called Musyawarah Guru Mata Pelajaran/ Consultative Meeting of Subject Teacher. It is a forum where the teachers share about their school condition, especially about their own subject. This forum called forum by, from and for the teacher. (Trisno, 2013). This forum motivates the teacher to develop their ability and skill in arranging the lesson plan, and also develop the teacher ability in teaching, and the forum where the teacher share about the development in education thing. They also share about the problem that they face, and then try to solve it together. The teachers who have observed said that the 2013 
curriculum training makes them more understands about several things in curriculum (Scientific approach and how to apply it, arranging the lesson plan based on 2013 curriculum and assessment based on 2013 curriculum) and the MGMP is forum where they can refresh their knowledge about 2013 curriculum when they were learned in 2013 curriculum training.

\section{E. CONCLUSION}

Based on the result of data analysis and the research findings and discussions in the previous chapter, the researcher concludes that:

1. The average score of teachers' teacher comprehension about the learning concept based on 2013 curriculum is 97 . It is in very good category.

2. The average score of teachers' ability in constructing lesson plan based on 2013 curriculum is 91 . It is in very good category.

3. The average score of teachers' ability in applying the scientific approach in the class is 95 with very good predicate.

4. The average score of teachers' ability in applying the assessment based on 2013 curriculum is 83 with good predicate.

\section{F. RECOMMENDATION}

Based on the result of this research, the researcher puts some suggestions as follow:

1. Sustaining the teachers' understanding and mastering about 2013 curriculum.

2. The teacher also spread their ability and understanding about teaching English based on 2013 curriculum to the other teacher who do not understand yet for the better education in Gowa.

\section{REFERENCES}

Carl, Arend E. Teacher Empowerment through Curriculum Development. Third edition. Cape Town: Juta\& Company. 2009

"Collins". English Language Teaching Online. http://www.collinsdictionary.com/dictionary/english/english-languageteaching (17 Maret 2015)

Dixie, Denny. "English History in Indonesia", blog Denny. http://duniadixie. blogspot.com/2011/12/english-history-in-indonesia.html ( 17 Maret 2014) 
Fadlillah. Implementasi Kurikulum 2013 dalam Pembelajaran SD/MI, SMP/MTS, dan $S M A / M A$. Yogyakarta: Ar-Ruzz Media. 2014

Hosnan. Pendekatan Saintifik Dan Kontekstual Dalam Pembelajaran Abad 21. Cet I; Jakarta: Ghalia Indonesia, 2014.

Kurnasih, Imas dan Berlin Sani. Implementasi Kurikulum 2013 Konsep dan Penerapan. Surabaya: Kata Pena. 2014

Larsen Diane-Freeman. Techniques and Principles in Language Teaching. Second Edition; Oxford: Oxford University Press, 2008.

Makmur, Arif Mansur. Tesaurus Plus Indonesia-Inggris. Jakarta:Penerbit Hikmah, 2009

Mulyasa. Pengembangan dan Implementasi Kurikulum 2013. Bandung: Rosda, 2013.

Richards, Jack C and Theodore S. Rodgers." Approaches and Methods in Language

Teaching". United States of America, United Kingdom: Cambridge University Press, 1986.

Rofik, Abdur. "School Readiness in Curriculum 2013 Implementation in English Lessons for State Junior High Schools in Wonosobo Regency" Tesis Pasca Sarjana Universitas Negeri Yogyakarta. 2014

Sanjaya, Wina. "Kurikulum dan Pembelajaran". Jakarta: Kencana Prenada Media Group, 2008.

Sudjiono, Anas. Pengantar Statistik Pendidikan, Jakarta: CV Rajawali, 1991.

Sugiyono, Metode Penelitian Pendidikan Pendekatan Kuantitatif, Kualitatif, dan R\&D”. Bandung: Alfabeta, 2013.

Sukirno. "The Implementation of Curriculum 2013 in the English Language Teaching and Learning at SMP 1 Kajen Pekalongan". Thesis Pasca Sarjana Universitas Negeri Yogyakarta. 2014

Trianto. Mendesain Pembelajaran Kontekstual di kelas. Jakarta: Cerdas Pustaka. 2008

Universitas Islam Negeri Alauddin Makassar. 2013. Pedoman Penulisan Karya Tulis Ilmiah: Makalah, Skripsi, Tesis, Disertasi, dan Laporan Penelitian. Makassar: UIN, 2013.

Yuliana Gazali, Rahita. "Penerapan Pendekatan Scientific dalam Pembelajaran Matematika SMP Kelas VII Materi Bilangan” Thesis Universias Negeri Yogyakarta .

Teaching Approach: The Grammar Translation Method". One Stop English http://www.onestopenglish.com/support/methodology/teachingapproaches/teaching-approaches-the-grammar-translationmethod/146493.article (17 Maret 2015). 